\title{
She Is My Manager: Druze Adolescence Attitudes toward Druze Women in Israel
}

\author{
Janan Faraj Falah $1,2,3$ \\ ${ }^{1}$ The Arab College for Education, Haifa, Israel \\ ${ }^{2}$ The Western Galilee College, Akko, Israel \\ ${ }^{3}$ Sakhnin College for Education, Sakhnin, Israel \\ Email: Jananf81@gmail.com
}

How to cite this paper: Falah, J. F. (2019). She Is My Manager: Druze Adolescence Attitudes toward Druze Women in Israel. Sociology Mind, 9, 290-301. https://doi.org/10.4236/sm.2019.94019

Received: February 11, 2019

Accepted: September 26, 2019

Published: September 29, 2019

Copyright (c) 2019 by author(s) and Scientific Research Publishing Inc. This work is licensed under the Creative Commons Attribution International License (CC BY 4.0).

http://creativecommons.org/licenses/by/4.0/

\begin{abstract}
The present study examines attitudes of Druze adolescent in Israel toward Druze women. It was conducted through questionnaires containing questions and statements. Some items related to relative's women, others to women in general. Some items expressed attitudes towards men. It tests the hypothesis that demographic variables influence attitudes toward women. Specifically, the study examined the influence of gender, parent's education, parent's profession, number of siblings, and religion on social status, education, and profession. The study assumed that community composition and particularly the percentage of Druze population within a community influences attitudes of Druze Adolescence toward women. The questionnaires were delivered to 100 Druze $12^{\text {th }}$ graders. They hailed from three villages: "Yarka, Pqein, and Abo Snan". The research findings indicate that there is a difference between the attitude of boys and of girls toward the status of women regarding education. Both groups, however, ranked education as more important than social status and profession. Residence influences attitude toward the women's status regarding education. Conclusions: 1) The Druze religious leaders (men not Women) influence the status of women and attitudes toward women. Influence varies among the villages. 2) The percentage of Druze in the settlement effects women's status. 3) Girls were more interested than boys in advancing attitudes towards women regarding social status, profession and education.
\end{abstract}

\section{Keywords}

Druze, Women, Adolescent Attitudes, Society, Israel

\section{Introduction}

The number of Druse worldwide is above one million and a half individuals, 
concentrated mainly in three countries, Syria, Lebanon and Israel (Dana, 1999). 700,000 Druze live in Syria, 215,000 in Lebanon and 32,000 in Jordan; about 300,000 living in Europe, the USA, South America and Australia (Shafir \& Peled 2002). There are 22 Druze villages in Israel. Israeli government statistics show that there were 150,000 Druze lived in Israel at the end of 2017, most living in the Galilee in the North of Israel. This number represents 1.5 per cent of Israel's population $n$ (Israel Central Bureau of Statistics, 2017).

According to Druze tradition, the Druze people have existed forever, but revealed their religion to the outside world during the "Time of Uncovering or Exposure" (Dor Elchashef) in the year 1017 (Kasem, 1991). The religion is based upon two main principles: reincarnation and brotherly protection (Dana, 1998). The latter belief has produced a sense of kinship and solidarity among Druze throughout the world (Faraj Falah 2016).

It is commonly believed that the Druze religion imposes hardships upon women. In fact, the opposite is true. The Druze religion is egalitarian (Izzeddin 1984). It prohibits polygamy and prohibits imposed marriages. It provides a woman the right to terminate a marriage that she deems inappropriate (Zaki, 1997) (Falah 2016).

The first great Druze lawmaker was Al-Amir Al-Sayid Abd-Allah Al Tanukhi who died in 1479 in Syria (Al Tanukhi, 1998) (Nasser 1997). Over five hundred years ago, he called for equality between men and women in religious observance and everyday life. He required each husband to help his wife get education and provide her a maid if she was unable to function alone. Al Tanukhi included the institution of marriage-based on the principles of equality and justice-among the principles of faith (Al Tanukhi, 1998) (Faraj Falah 2013).

The Druze in Israel have traditionally been cut off from Israeli society. This stems from: secret aspects of religious belief and observance, prohibition against intra-faith marriage (Faraj Falah 2018), and geographical isolation from cultural centers in Israel (Layish, 1985). Over the past two decades, however, the Druze community has begun to open itself to the outside. This is due to Israeli laws imposing compulsory military service on Druze males in 1956 (Falah, 2000) and recognizing the Druze as an independent sect in 1957 (Layish, 2000). Druze young men serving in the Israeli army come in contact with Israeli people and culture. This contact has influenced Druze men directly and Druze women indirectly. Gaining legal recognition has permitted the Druze to gain government funding and resources (Blanck, 1971).

Druze women in Israel lack political power. The community has only recently established women's organizations. In the area of education, women have made progress. While more Druze girls than ever are attending school, little else has changed (Faraj Falah 2009).

Druze religious leaders exert great power over the Druze population (Faraj Falah 2018). They can legislate laws and excommunicate members from the house of prayer. Religious leaders have exploited the secrecy inherent in the Druze religion to exercise social control in their villages and impede women's 
advancement (Faraj Falah 2006) (Faraj Falah 2005).

\section{Theoretical Background}

\subsection{The Druze in Israel}

According to the Central Bureau of Statistics, by the end of 2017, the Druze community in Israel was about 139,000 people, $1.6 \%$ of the general population of Israel. The Druze community is spread in 19 villages (17 villages in the Northern Province of Israel and two in Haifa District), with total fertility rate of (the average number of children a woman is having during a lifetime) of 2.2 children within 36,000 households, when the average age of the first marriage is 27.7 for men and 23.0 for women. It should be noted that according to the Central Bureau of Statistics there is a great gap between the number of the working men (68.6\%) and the number of the working women (only 33.7\%).

The Druze, throughout history, has maintained good relations with the Jewish Nation, had supported the establishment of Israel and made a pact with the State. In 1957 the Druze had gained recognition by the Minister of Religious Affairs as an "independent religious community", and in October 1961, the Druze Religious Council (3 members) was recognized as the main spiritual authority. The process was completed on the 25th of December, 1962 with the approval of the Knesset of the Druze Religious Court to manage all Druze religious affairs. It is important to notice the religious distinction within the community, some Druze choose to be religious (the Ukal) with a clear definition of dressing code, cus-toms and lifestyle, and some are secular (Johal), yet, the religious leaders also responsible beyond religious matters (Shtrukman, 2010). In addition, the Druze religion prohibits polygamy and women are equal to men, thus, women are entitled to perform any religious role, as well as to equal inheritance (Faraj-Falah, 2016a).

The Druze community conducts conservative traditional patriarchal lifestyle (Amarani, 2010; Halabi \& Shamai, 2016) (Faraj-Falah, 2016b) with a constant concern to maintain the Druze core values and tradition such as Druze religion, tradition, independence and relation to land (Falah, 2000). The Druze family is characterized by a distinct hierarchy, which is emphasized by an absolute rule of the father on the extended family-his wife, sons, daughters, the sons' brides and offspring. They all required to abide by the family elders and to put the family goals in priority to personal ones (Dana, 2003). In this manner women's inferior status within the family is obvious, they are required to take care of the household and children, to dress modestly, to avoid contact with strangers and to obey their husbands. However, the status of women in the Druze society is not static and it constantly improves and empowered, as they grow older, mainly, as a result of their sons' marriage and the establishment of their own family units near their parents and to the increase of the extended family. The mothers' experience and involvement in their sons' marriage, the family affairs and the interaction with their brides, who are bide to obey the mother in law, only strengthen their status within the family (Vinner-Levi, 2005a; Vinner-Levi, 2005b). 
Researcher (Faraj Falah, 2005) indicate that since the 1990s it is clear that the Druze society is undergoing changes in all life aspects due to the following processes: 1) the young generation prefers living independently, thus, the ex-tended family weakens. The focus is on the nuclear family of parents and children only. One element which accelerated this modification is the establishment of the new veterans' neighborhoods which totally differ from the traditional ones of the elder population. Second element The younger generation's independence, along-side with the increase of higher education, have undermined the authority of the religious much older traditional leadership. Third element is, $83 \%$ of the young Druze men, who take part in the compulsory army service, are exposed to different lifestyle, thus, the affinity to the clan (the extended family) weakens. 2) The progress in education has led to a change in the perception of the family role. 3) The frequent visits to the cities for the aims of working, entertainment or studying also have contributed to the exposure to the western culture. 4) Employment changes-the transition from a rural traditional source of income into other sources outside the Druze villages. 5) The change in the status of women by education and work. 6) The transition from the village to the city as part of the urbanism. 7) As opposed to the old, traditional, religious leadership, a new generation which has gained great power and senior governmental and security positions has risen. These changes have led to tension and division between the religious and secular parts within the community, to the point of declaring that "the community members (the seculars) are becoming apart from their basic values, no values and no limits".

\subsection{Druze Women's Seeking for Work-Difficulties and Barriers}

Faraj Falah (2016a) claims that the Druze woman always has worked beside her husband, she was responsible mainly for the farming and soil in the field and then was coming home to continue maintaining the household, from cleaning to cooking. Thus, the decrease in agriculture-the main source for bread, had damaged badly the Druze sector, and as a result, the Druze woman, who is subjected to residential radius restriction (Falah, 2000; Faraj Falah, 2005; Faraj Falah, 2018). Vinner-Levi (2004) claims that the Druze women in Israel suffer from twice over discrimination: one time is due to the fact that the community is a minority in a State which the employment opportunities for the Arab population in general and for women, in particular, are limited, and secondly, for being part of traditional and rigid society which restricts women from working outside their villages due to cultural-traditional reasons. The minority of Druze women who work is limited to specific professions and roles, in which, the salary is poor, such as community services, social services and industry-mainly in textile and food industries established by Jewish entrepreneurs within the Druze villages. Yashiv \& Cisar (2013) claim, on the other hand that, although the Druze woman's status is changing and there are more women that work in high-paying professions and senior positions, still, their integration in the Israeli labor mar- 
ket, in general, is poor, and they do not play a significant role in the Israeli economy in general or in their own family in particular, for the incentives to gain education and other social skills are minor. Fichtelberg (2004) argues that prejudice also makes integration in the Jewish labor market harder, due to traditional barrier of appearance, especially among religious women with religious-traditional clothing - as the head-cover for instance. The language-the non-native Hebrew, is also a barrier that prevents women from entering well-paid jobs and major professions, urging them to work in "small businesses" and in manufacturing, or at any service which does not require speaking the Hebrew language. Another barrier is the religious leaders of the community, who are against the work of women outside home and against academic studies, which sometimes compel women to sleep outside their homes and expose them to modern society (Faraj-Felah, 2005; Faraj-Falah, 2018).

\subsection{The Phase of Academic Studies}

The inferior status of the Druze women and their position on the margins of society and family hierarchy have made studying in higher education extremely difficult, especially the fact that some Druze villages lack of high schools in the past. Nevertheless, three decades ago, in the 1980s, Druze women in Israel began studying at universities, facing the traditional conservatism in the community, and the prohibition to leave the village without an escort of man or staying and sleeping in a mixed society or city for example. Therefore, very few families allowed their daughters to study, yet, over the years, Druze girls have joined the studying circle, breaking the social and traditional barriers. Hence, at present time, many Druze women enter universities and academic colleges (Falah, 2000). Furthermore, during their studies, Druze women are exposed to western, democratic values, which are fundamentally different from their traditional community (Al haj, 1996). The decision to purchase higher education has modified their inferior, poor status. Thus, the distinguished status that these educated Druze women had acquired within the community, had led parents to send their daughters to study in the higher education system. These women challenge the old traditional norms and enable others to follow their path and to generate the social change for Druze women. Gaining of education enables working outside home and outside the close surroundings radius, and to be exposed to knowledge, a different way of thinking and other innovative perceptions, along with other social involvement (Faraj Falah, Maman. 2019). This process created "a quiet revolution" that affects the social structure and the status of the Druze woman in general. The unique nature of the change was the fact that it was not a "western feminist revolution" towards feminine world-unity, and not against the "masculine world" either, in fact, its main power was for being almost invisible, and thus, could not be immediately repressed. Those women, who seek to modify their status, on the one hand challenge traditional, and on the other hand, maintain the norms and tradition. Their main purpose is to break through the 
barriers of repression and to allow other women to be also part of the process (Vinner-Levi, 2004). However, for these traditional women, taking part in higher education is extremely empowering interculturally, for they become aware to the inequality and the gap between competence and traditional restrictions, which create constant difficulty in daily routine. Education has led women to gain knowledge and be open-minded, to work and earn money, yet, in many ways, education was not the liberating factor, merely an awareness-raising factor of equality, patriarchal domination and oppression, thus, along with feeling proud and successful, they also felt pain (Vinner-Levi, 2006). Today, the Druze perceive the "ideal woman" differently, if once a woman was judged by religious ruling and her personal status was based on Druze religion and traditions, today, her status is based on modern-cultural perceptions (Moadi, 1998). On the other hand, claims that the social structure of the Druze community is not homogenous, hence, processes of modernization do not enter equally to all Druze communities, therefore, some of the Druze communities are more conservative than others, that is to say, some Druze communities maintain the values and tradition more than others.

\subsection{Education in the Druze Sector}

Education in the Druze sector has undergone great changes over the years, in order to examine education in the Druze sector, two public committees have been established-the "Ben-Dor Committee", headed by Prof. from Haifa University, and "Shechterman Committee", headed by the Knesset member Shechterman, who was, at that time, the Head of the Knesset Education and Culture Committee (Falah, 2000; Falah-Faraj, 2005). The two committees recommended to exclude the sector from the Arab education system and to integrate the sector within the general one. Those recommendations were carried out, and the Druze education sector became independent in 1976. The educational system includes elementary and higher education. Falah-Faraj (2005) indicates that in the past, until the third or fourth grades, boys and girls had learned together and were separated afterwards. In the village of Majar, for example, boys and girls had separate schools. According to the researcher, this separation of genders indicates conservative perception and restrictions of women, which had prevented from them (the women) to break through the suffocating barriers and restrains until this day.

\subsection{Women Principals}

In the modern, constantly developing era of today, it is evident that women have managed to break through the barriers and to serve in various positions that once were defined as appropriate for men only, especially in the field of education. Thus, Druze women find themselves managing schools, yet, the nature of their successful management is relatively limited. Naturally, the subject has been examined, some believe that since the principals operate in an environment characterized by male hegemony, in view of differences in the process of sociali- 
zation and life experience, significant differences in gender management can be discerned managing bin masculine environment, and in the light of differences in socialization process and life-experience, there must be significant differences in management style. Moreover, the gender differences indicate of distinction between the way women did to acquire their status, and they also indicate the differences in the way women experience the process. Others argue that gender identity is formed and developed by the role and position in accordance with the context of activity. Some researchers believe that there are no substantial gender differences in managing style. Female school principals in the Druze sector are women with higher-academic education, who have invested great time and efforts as teachers and were promoted to executive position, and in this manner, acquired their respect and status, becoming a role model for other women, facing the conservative's sheikhs who constitute the main barrier for many young Druze. It should be noted that the first female school manager in the Druze community was Mrs. Salma Kasem Falah, who was appointed to the post in 1960 (only after 25 years additional women were appointed too). At present, there are several Druze women who run elementary and high schools. In addition, there are many women who succeeded in other fields and senior positions such as $\mathrm{Mrs.} \mathrm{Hu}$ ria Shami Birani from Daliat El-Carmel, who was the first Na'amat Coordinator in the early 1960s. The first Druze woman who got an academic degree is Mrs. Samira Abu Rokken from Ausafiain the early 1970s (Falah-Faraj, 2005).

\section{Research Methodology}

The present study examines attitudes of Druze Adolescence in Israel toward Druze women. It tests the hypothesis that demographic variables influence attitudes toward women. Specifically, the study examined the influence of: gender, parent's education, parent's profession, number of siblings, and religion on: social status, education, and profession. The study assumed that community composition - and particularly the percentage of Druze population within a community-influences attitudes of Druze Adolescence toward women.

Dependent and independent variables were identified. The independent variables included: village of origin, gender, school, study track, class, number of siblings, mother's education (years of schooling), father's education (years of schooling), mother's occupation, and father's occupation. The dependent variables were: occupation, social status, and education.

The study was conducted through questionnaires containing questions and statements. Some items related to relatives, others to women in general. Some items expressed attitudes towards men, such as: "Men are smarter than women"; or "I respect a man who helps his wife with housework". Behavior is rooted in the environment, beliefs, values and ideologies of the "subject" (Pelto \& Pelto, 1978). Most of the field-work was based on in-depth ethnographic interviews as the prime source for information, allowing the applicant to tell her story freely, and at the same time, to remain focused on the research questions (Kapel-Green 
\& Mirsky, 2013; Shkedi, 2011; Faraj-Falah, Maman, \& Amasha, 2017; Maman, Faraj-Falah, \& Napso, 2018).

Respondents were male Druze and $12^{\text {th }}$ graders. They hailed from three villages:

Yarka, Pqein, and Abo Snan. The villages are distinguished by the percentage of Druze within their total population. Yarka is 100\% Druze; Pqein consists of 78\% Druze, with the remaining 22\% consisting of Moslems and Christians. The majority of the population of Abo Snan is Christian and Moslem; Druze comprise $31 \%$ of the population.

One hundred male and female high school students were selected from the villages of Yarka, Pqein, and Abo Snan. Each was given a questionnaire containing 40 questions and statements regarding attitudes towards women. Respondents were asked to supply personal demographic and background data.

Pertinent Sampling Data:

Religion:

The percentage of Druze students in the high school population is as follows:

Pqein 96.43\%; Yarka 100\%, and Abo Snan 34.62\%. These percentages correspond to the total Druze population in each village.

Gender:

In Pqein, $46.43 \%$ of the respondents were girls and $53.57 \%$ boys.

In Yarka, $75 \%$ of the respondents are girls and $25 \%$ boys.

In Abo Snan, the girls are $69.23 \%$ and the boys $30.77 \%$.

Siblings:

Pqein $55.56 \%$ of the respondents had 7 - 15 siblings.

Yarka $67.86 \%$ of the respondents had 4 - 6 siblings;

Abo Snan 50\% of participants had 4 - 6 siblings.

Mother's education (years of formal learning):

Pqein $73.33 \%$ - 0 - 9.

Yarka 60.67\% - 0 - 9.

Abo Snan 72\% - 0 - 9 .

Father's education (years of formal learning):

Pqein 52.17\% - 10 - 12.

Yarka 53.57\% - 12+.

Abo Snan 60.87\% - 10 - 12.

Mother's occupation:

Pqein 77.55\% homemakers.

Yarka 89.29\% homemakers.

Abo Snan 68\% homemakers.

The questionnaire contained two sections:

Section A provided demographic information regarding participants': gender, religion, number of siblings, parents' education, and mother's profession (For distribution of the demographic variables, (see Table 1). The second part revealed attitudes towards women in: education, occupation, and social status. 
Section B contained 40 attitudinal statements regarding women. Respondents were asked to record extent of agreement to each statement on a scale of $1-6$. Statements related to the three areas described earlier (Distribution of the items by fields is seen in Table 2).

In addition, the questionnaire asked respondents whether they planned to continue their academic studies and, if so, where.

Table 1. Population distribution.

\begin{tabular}{ccccc}
\hline Village & Druze & Moslems & Christians & Total \\
\hline Yarka & $100 \%$ & - & - & 20000 \\
Pqein & $78 \%$ & $1.2 \%$ & $20.7 \%$ & 5600 \\
Abo Snan & $30.2 \%$ & $54 \%$ & $15.8 \%$ & 13,000 \\
\hline
\end{tabular}

Table 2. General description of data (Demographic distribution).

\begin{tabular}{|c|c|c|c|c|c|c|c|}
\hline \multirow{2}{*}{ Variable } & \multirow{2}{*}{ Categories } & \multicolumn{2}{|c|}{ Pqein N-56 } & \multirow{2}{*}{$\begin{array}{c}\text { Yarka N-28 } \\
\text { Freq. }\end{array}$} & \multicolumn{3}{|c|}{ Abo Snan N-26 } \\
\hline & & Freq. & $\%$ & & $\%$ & Freq. & $\%$ \\
\hline \multirow[t]{3}{*}{ Religion } & Moslem & 1 & 1379 & 0 & 0 & 6 & 23.08 \\
\hline & Druze & 54 & 96.43 & 28 & 100 & 9 & 34.62 \\
\hline & Christian & 1 & 1.79 & 0 & 0 & 11 & 42.31 \\
\hline \multirow[t]{2}{*}{ Gender } & Female & 26 & 46.43 & 21 & 75 & 16 & 69.23 \\
\hline & Male & 30 & 53.57 & 7 & 25 & 8 & 30.77 \\
\hline \multirow[t]{14}{*}{ No. Siblings } & 1 & 0 & 0 & 0 & 0 & 1 & 4.17 \\
\hline & 2 & 1 & 1.85 & 0 & 0 & 3 & 12.5 \\
\hline & 3 & 3 & 5.56 & 5 & 17.86 & 5 & 20.83 \\
\hline & 4 & 4 & 7.41 & 9 & 32.14 & 2 & 8.33 \\
\hline & 5 & 9 & 16.67 & 7 & 25 & 7 & 29.17 \\
\hline & 6 & 7 & 12.96 & 6 & 10.71 & 3 & 12.5 \\
\hline & 7 & 7 & 12.96 & 2 & 7.14 & 0 & 0 \\
\hline & 8 & 7 & 12.96 & 1 & 3.57 & 0 & 0 \\
\hline & 9 & 7 & 12.96 & 0 & 0 & 1 & 4.17 \\
\hline & 10 & 4 & 7.41 & 0 & 0 & 2 & 8.33 \\
\hline & 11 & 2 & 3.7 & 0 & 0 & 0 & 0 \\
\hline & 12 & 1 & 1.85 & 0 & 0 & 0 & 0 \\
\hline & 13 & 1 & 1.85 & 0 & 0 & 0 & 0 \\
\hline & 15 & 1 & 1.85 & 1 & 3.57 & 0 & 0 \\
\hline \multirow[t]{3}{*}{ No. Siblings } & $1: 1-3$ & 4 & 7.41 & 5 & 17.86 & 9 & 37.5 \\
\hline & $2: 4-6$ & 20 & 37.04 & 19 & 67.86 & 12 & 50 \\
\hline & $3: 7-15$ & 30 & 55.56 & 4 & 14.29 & 3 & 12.5 \\
\hline Mother's & $0-9$ yrs. & 33 & 73.33 & 18 & 60.67 & 5 & 20 \\
\hline \multirow[t]{2}{*}{ Education } & $10-12$ yrs & 9 & 20 & 8 & 25.93 & 18 & 72 \\
\hline & $12+$ yrs. & 3 & 6.67 & 2 & 7.41 & 2 & 8 \\
\hline Father's & $0-9$ yrs. & 14 & 30.43 & 6 & 21.43 & 1 & 4.35 \\
\hline \multirow[t]{2}{*}{ Education } & $10-12$ yrs & 24 & 52.17 & 7 & 25 & 14 & 60.87 \\
\hline & $12+$ yrs. & 8 & 17.39 & 15 & 53.57 & 8 & 34.78 \\
\hline Mother's & No Work & 38 & 77.55 & 25 & 89.29 & 17 & 68 \\
\hline Profession & Yes Work & 11 & 22.45 & 3 & 10.71 & 8 & 32 \\
\hline \multirow[t]{3}{*}{ Class } & Literature & 22 & 39.29 & - & - & - & - \\
\hline & Science & 26 & 46.43 & - & - & - & - \\
\hline & Technology & 8 & 14.29 & - & - & - & - \\
\hline
\end{tabular}




\section{Research Findings}

1) There is a difference between the attitude of boys and of girls toward the status of women regarding education. Both groups, however, ranked education as more important than social status and profession. Residence influences attitude toward the women's status regarding education. In Abo Snan, the status of the woman is perceived more positively, followed by Pqein which is a mixed village with a Druze majority. The most negative attitudes were given by residents of the village of Yarka that is all Druze.

2) There is a clear difference between boys and girls in attitudes towards woman's profession. The gap is the largest between the boys and the girls was recorded in Yarka.

3) Boys were more negative than girls regarding the woman's social status. Place of residence influences attitude regarding social status, such that students from Abo Snan show a more positive outlook than the students from the other two villages.

4) Both genders were opposed to change in tradition expressed in such questions as: "Do you agree to your sister having a boyfriend before marriage?" or "Do you agree to mixed marriage between Druze and non-Druze couples?"

\section{Conclusion}

1) The Druze religious leaders (men not Women) influence the status of women and attitudes toward women. Influence varies among the villages. Religious leaders in Yarka (100\% Druze) for example, exerted a greater influence than leaders in either Pqein or Abo Snan.

2) The percentage of Druze in the settlement effects women's status. In Abo Snan where the Druze are a minority, her status is higher than in Pqein where the Druze are the majority and her status in Yarka where all of the residents are Druze.

3) Girls were more interested than boys in advancing attitudes towards women regarding social status, profession and education.

4) Respondents of both genders support tradition.

5) Respondents of both genders support educating women.

6) Despite the presence of women's organizations in the villages, men continue to enjoy a higher status than women.

\section{Recommendations}

1) The education must play a key role in changing attitudes towards women.

2) Improving the fundamental educational and social change within the Druze community.

3) Educational change begins with alterations in curriculum (Faraj Falah 2013). These include:

- selecting texts that portray women in dominant family roles;

- selecting materials written by women; 
Social change includes:

- allowing educated men and women lay persons to serve as religious leaders;

- developing women's organizations in all Druze villages, thereby introducing Druze women to successful women from diverse social groups;

- Encouraging contact between educated lay leaders and religious leaders.

\section{Conflicts of Interest}

The author declared no potential conflicts of interest with respect to the research, Authorship, and/or publication of this article.

\section{References}

Abu Izzeddin, N. (1984). The Druze: A New Study of their History, Faith and Society. New York: Leiden.

Abu Zaki, P. (1997). Al-Amir Al-Sayid. Lebanon: Al Miktaba Al Maa'ruphia.

Al Haj, M. (1996). Education among Arabs in Israel. Jerusalem: Magnes, Floressheimer Institute, The Hebrew University of Jerusalem.

Al Tanukhi, A. (1998). Tashria Zawaj Al-Mowahdin WAlmowahidat Watalakohom. Lebanon: Al Maktaba Al Maa'ruphia.

Blanck, H. (1971). The Druse. Jerusalem: Prime Minister's Office, The Office of the Advisor for Arab Affairs. (In Hebrew)

Dana, N. (1998) The Druze Theory and Practice. In N. Dana (Ed.), The Druze. Abo Snant Gan: Bar Ilan University.

Dana, N. (1999). The Druze in Israel. Jerusalem: The Jerusalem Institute for Public and State Issus.

Falah, S. (2000). The Druze in the Middle East. Jerusalem: Ministry of Security Press.

Faraj Falah, J. (2005) The Druze Woman. Barki Sfarim: Reshon Latzion.

Faraj Falah, J. (2006). Attitudes of Druze Youth in Israel toward Druze Women. In M. Fialkoff, \& P. Kirmayer (Eds.), Adult Education in Israel (Vol. 9, pp. 182-188). Jerusalem: Division of Adult Education.

Faraj Falah, J. (2009). Widows in Druze Society. Gender, 26, 247-252. https://doi.org/10.1007/s12147-009-9079-7

Faraj Falah, J. (2013). The Portrayal of Women in Israeli Arabic Textbooks on Druse Heritage. US-China Education Review A, 3, 33-37.

Faraj Falah, J. (2016a). She Is a Widow: The Story of Six Druze Widows in Israel. Open Journal of Social Sciences, 4, 210-226. http://www.scirp.org/journal/js

Faraj Falah, J. (2016b). The Status of Druze Women in the Druze Religious Law in Comparison to Druze Women's Status in Society. International Journal of Multidisciplinary Research and Development, 3, 203-206.

Faraj Falah, J. (2018). Does Multicultural Education Affect the Druze Heritage Curriculum? Open Journal of Social Sciences, 6, 257-271.

https://doi.org/10.4236/jss.2018.61019

Faraj-Falah, J., \& Maman, Y. (2019). "Pioneers"-The Druze Women School Principals as Role Models \& Generators of Social Change. Creative Education, 10, 1573-1588.

https://doi.org/10.4236/ce.2019.107114

Fichtelberg (2004). The Participation of Palestinian Woman in the Labor Force in the 
Past Decade. Qeriat Ben Gorion: The Ministry of Labor and Social Affairs of the Authority of Personnel Planning.

Kasem, F. S. (1991). Nebras Almowahdin, Akko. Dar AlJAlil.

Layish, A. (1985). Taqiyya among the Druze. Asian and African Affairs, 19, 245-281.

Layish, A. (2000). Rules, Customs and Laws in the Issue of Druze Personal Status. In S. Falah (Ed.), The Druze in the Middle East. Jerusalem: Ministry of Security Press.

Moadi, C. (1998). The Druze Woman. In D. Nissim (Ed.), The Druze (pp. 111-119). Ramat Gan: Bar-Ilan University.

Nasser, M. (1997). Al Mowahdin Al-Druze Fi Al Islam. Lebanon: Al Dar Al Islamia. (In Arabic)

Pelto, P., \& Pelto, G. (1978). Anthropological Research: The Structure of Inquiry. Cambridge: Cambridge University Press. https://doi.org/10.1017/CBO9780511607776

Shafir and Peled (2002). American Druze Heritage. International Middle East Media Center, Yiftachel and Segal.

Vinner-Levi, N. (2004). "I Am a Bird, Yet Not Flying" The Identity of the First Druze Women Who Applied for Higher Education. Doctoral Thesis, Jerusalem: The Hebrew University of Jerusalem.

Vinner-Levi, N. (2005a). "I Was Called Umm al-Futa": Higher Education as an Intercultural Encounter.

Vinner-Levi, N. (2005b). Higher Education as an Encounter of Opinion, Society and Culture. Changes in the Identity of Pioneer Druze Women in Acquiring Higher Education. Social Issues in Israel-Social Journal, No. 1, 5-30.

Vinner-Levi, N. (2006). The Work of the First Female Druze Teachers-Towards the Promotion of Education and to the Change of Gender Roles among Their Students. A Research Report Submitted to The Mofet Institute. Tel Aviv-Yafo: The Mofet Institute. 